Short communication

\title{
Air Pollution during Asbestos Removal
}

\author{
Gabriela Sąkol $^{1 *}$, Maja Muszyńska-Graca² \\ 'Department of Biohazards and Immunoallergology, Institute of Occupational Medicine \\ and Environmental Health, Sosnowiec, Poland \\ ${ }^{2}$ Department of Environmental Health and Epidemiology, Institute of Occupational Medicine \\ and Environmental Health, Sosnowiec, Poland
}

Received: 26 September 2017

Accepted: 28 December 2017

\begin{abstract}
Fibrous asbestos, including chrysotile, amosite, and crocidolite, is a dangerous health hazard, but valuable for technical applications. The goal of workplace air monitoring, performed in the period 2000-2005, was to establish the differences in exposure to asbestos of construction workers. We demonstrated that the geometric mean of respirable fibres concentration at blocks of flats was 3-fold higher $(\mathrm{p}<0.01)$ than that at cooling towers $\left(0.14 \mathrm{f} . / \mathrm{cm}^{3}\right.$ and $0.05 \mathrm{f} . / \mathrm{cm}^{3}$, respectively). However, for total dust concentration the relationship was reversed. The geometric mean of the total dust concentration during work at a block of flats $\left(1.9 \mathrm{mg} / \mathrm{m}^{3}\right)$ compared with one during the removal of cooling towers $\left(5.9 \mathrm{mg} / \mathrm{m}^{3}\right)$ was significantly lower $(\mathrm{p}<0.01)$. The applicable hygiene standards for exposure to asbestos were exceeded in $93.0 \%$ (buildings) and $93.3 \%$ (cooling towers) results of measurements.
\end{abstract}

Keywords: removal of asbestos, occupational exposure, residential buildings, cooling towers

\section{Introduction}

Fibrous asbestos, including chrysotile, amosite and crocidolite, is a dangerous health hazard, but valuable for technical applications. Cement sheets containing asbestos fibres have been widely used in Poland in the building and construction industry. Current legislation calls for materials containing asbestos to be removed. The legislature has defined the occupational limit value for concentration of respirable fibres $\left(0.1 \mathrm{f} . / \mathrm{cm}^{3}\right)$ and total dust $\left(0.5 \mathrm{mg} / \mathrm{m}^{3}\right)$, and has initiated the control measurements in the workplace. The comparison of the occupational exposure to asbestos of workers who have been renovating residential buildings with those who

*e-mail: g.sakol@imp.sosnowiec.pl have been working at industrial cooling towers revealed differences.

In the newest study, Szeszenia-Dąbrowska and Świątkowska [1] emphasized that the data on exposure to asbestos of removal workers was derived from random checks. Because limited workplace air monitoring data exist, the aim of this study was to complete the knowledge of the exposure to asbestos of construction workers during removal of asbestos-cement (A-C) sheets from different types of buildings.

\section{Material and Methods}

The first group of buildings were 10-storey blocks of flats covered with a-c sheets, located in the residential estates of Silesian cities. Flat A-C sheets were pressed 
and one side painted. The rough, naked eye diagnosis showed no corrosion damage. The A-C sheets were fastened on wooden scaffolds with planks filled by heavily damaged and crumbling mineral-wool. Work practices on scaffolding for stripping a-c sheets were named "During stripping." Other workers had taken over the stripped boards on scaffoldings and transferred asbestos waste to a storage place. The second group of objects were cooling towers built at industrial territories on the outskirts of cities. A fill inside a cooling tower was made with a lot of vertical corrugated A-C sheets inserted into steel components. A-C sheets were continuously washed by hot water, which led to their corrosion. A-C sheets in fills were badly damaged. They cracked while being removed. The tasks that performed in a fill at cooling towers were named "During removal." The term "Transfer into container" means carrying asbestos waste to a storage place, including also taking over A-C sheets inside the fill of a cooling tower. Our assessment of exposure to asbestos of removal workers was based on analysis of the data set from 153 personal measurements performed at residential buildings (76) and at industrial cooling towers (77) in the period 2000-2005. We had compared our archive data with current maximum admissible concentration (MAC) value. In addition, we used detailed observations of job tasks, work procedures, or practices during sampling.

The study was accomplished according to the NIOSH phase-contrast microscopy method 7400 for asbestos (PCM) [2]. Polish Regulations [3-4] calculate occupational exposure to asbestos based on respirable fibre concentrations together with total dust concentrations. Since $2005 \mathrm{MAC}$ is $0.1 \mathrm{f} / \mathrm{cm}^{3}$ and $0.5 \mathrm{mg} / \mathrm{m}^{3}$. In our research over 6 hours of workplace air samplings represent full-shift exposure. The sampling pump model AFC 123 (Casella Ltd, UK) was used. Asbestos dust was collected on mixed cellulose esters membrane filters type AA $(0.8 \mu \mathrm{m}$ pore size) (Milipore, UK). The transparency was achieved using an acetone vaporizer VAP 200 (BGI Inc., USA). Fibres were counted and sized at 500x magnification in the positive-contrast microscope MAZ (PZO, Poland), with Walton-Beckett graticule type G-22 (Graticules Ltd, UK). Furthermore the estimation of amount was conducted between asbestos and mineral wool fibres. Mineral wool fibers were distinguished based on the gross fiber morphology and their optical properties. Total dust samples collected on polypropylene filter Fipro-25 (Textile Institute, Poland), were weighed with $0.01 \mathrm{mg}$ accuracy on semi-microbalance Genius ME (Sartorius, Germany). The data of dust concentrations was supplemented with results of $\mathrm{x}$-ray diffraction of the bulk samples of removed items according to the procedure described by Sakol et. al. [5]. The results of sampling were analyzed using STATISTICA Version 7.1 software (StatSoft Inc., USA). The distribution of random variables was determined with Shapiro-Wilk's test, accepting $\mathrm{p}$-value $=0.05$. The statistical differences of compared groups (within and across removed construction and work tasks) were examined by MannWhitney U test.

\section{Results and Discussion}

Results given as geometric means (GM) were tabulated in Table 1. The respirable fibre concentrations of all tasks at the block of flats compared to those at cooling towers were significantly higher $(\mathrm{p}<0.01)$. The amount of mineral wool fibres in personal samples of workers who have performed building renovations (sized in Table 2) was estimated in the range 1.3-58.1\%. During removal of asbestos in both types of buildings, asbestos fibers in the workers breathing zone were short and thin. More than half of the dimensioned fibres were in the range 5-10 $\mu \mathrm{m}$ with diameters thinner than $1 \mu \mathrm{m}$.

However, for total dust the relationship was reversed. The total dust concentrations "During stripping" at the block of flats compared to the "During removal" at the cooling towers were, significantly, 3 -fold lower $(p<0.01)$. Also, the respirable fibre concentrations of "During transfer into container" and all tasks together ("Total") at blocks of flats were about 3-fold higher than those at cooling towers. There was no significant difference. More than $90 \%$ of 8 -hour time-weighted averages of total dust concentrations were above the current valid value of MAC.

All samples of flat A-C sheets from blocks of flats (13) contained only chrysotile asbestos (10-12\% of mass). Corrugated sheets used in industrial construction (15 samples) were admixed with $\sim 10 \%$ chrysotile and $\sim 3 \%$ crocidolite asbestos. Many publications and databases regarding exposure to asbestos omit the issue of the concentration of total dust [1, 6-7]. Based on the data of Table 1 we found that employees carrying out works at residential blocks were exposed to higher concentrations of respirable asbestos fibres than those at industrial buildings. At the blocks of flats, the A-C panels stripping generated the highest fibre emissions among the renovation activities. The maximum concentration to which workers breaking away sheets were exposed was $0.90 \mathrm{f} / \mathrm{cm}^{3}$. Similar values $\left(1.1 \mathrm{f} / \mathrm{cm}^{3}\right)$ were obtained by Brown [8] when removing heavily damaged A-C boards in Australia. Only a little lower concentration $\left(0.84 \mathrm{f} / \mathrm{cm}^{3}\right)$ was found during the transfer of waste to the container. During the renovation of both residential and industrial buildings, workers transferring asbestos waste to the containers often worked in the same workspace as the ones stripping a-c sheets. This may be why there is no statistically significant difference between exposure to asbestos fibres of those two groups of workers. The asbestos fibre concentrations average of workers employed at blocks of flats was $0.14 \mathrm{f} / \mathrm{cm}^{3}$. Similarly, workers who were removing old homes in Tehran were exposed to $0.15 \mathrm{f} / \mathrm{cm}^{3}$ asbestos fibres, as the Kakooei and Normohammadi state [9], also based on the results of personal measurements. Mannetje [10] reported $0.03 \mathrm{f} / \mathrm{cm}^{3}$ as PCM median of time- 
Table 1. Total dust and respirable asbestos fibre concentrations and extent at or above the current maximum admissible concentration (MAC) during renovation of blocks of flats and cooling towers.

\begin{tabular}{|c|c|c|c|c|c|c|}
\hline \multirow[b]{2}{*}{$\begin{array}{c}\text { Name } \\
\text { of workplace }\end{array}$} & \multirow[b]{2}{*}{$\begin{array}{c}\text { Type of work } \\
\text { with a-c sheets }\end{array}$} & \multirow[b]{2}{*}{$\mathrm{n}$} & \multicolumn{2}{|c|}{ Total dust } & \multicolumn{2}{|c|}{ Respirable $^{* * *}$ fibres } \\
\hline & & & $\begin{array}{c}\text { Concentration } \\
\mathrm{x}_{\mathrm{g}}(\mathrm{GSD}) \\
\mathrm{x}_{\min }-\mathrm{x}_{\max }\left(\mathrm{mg} / \mathrm{m}^{3}\right)\end{array}$ & $\begin{array}{c}\text { Extent of MAC } \\
\%\end{array}$ & $\begin{array}{c}\text { Concentration } \\
\mathrm{x}_{\mathrm{g}}(\mathrm{GSD}) \\
\mathrm{x}_{\min }-\mathrm{x}_{\max }\left(\mathrm{f} / \mathrm{cm}^{3}\right) \\
\end{array}$ & $\begin{array}{c}\text { Extent of MAC } \\
\%\end{array}$ \\
\hline \multirow{3}{*}{ Block of flats* } & During stripping & 33 & $\begin{array}{c}2.1^{\mathrm{a}}(2.07) \\
0.6-8.1\end{array}$ & 95.1 & $\begin{array}{c}0.20^{\mathrm{b}}(2.74) \\
0.03-0.90\end{array}$ & 41.5 \\
\hline & $\begin{array}{c}\text { Transfer } \\
\text { into container }\end{array}$ & 43 & $\begin{array}{c}2.7(12.85) \\
0.3-45.8\end{array}$ & 91.1 & $\begin{array}{c}0.18^{\mathrm{c}}(2.77) \\
0.24-0.84\end{array}$ & 44.4 \\
\hline & Total & 76 & $\begin{array}{c}1.9(3.06) \\
0.3-45.8\end{array}$ & 93.0 & $\begin{array}{c}0.14^{\mathrm{d}}(3.02) \\
0.03-0.90\end{array}$ & 43.0 \\
\hline \multirow{3}{*}{ Cooling tower $^{* *}$} & During removal & 34 & $\begin{array}{c}6.7^{\mathrm{a}}(2.22) \\
0.9-46.3\end{array}$ & 100 & $\begin{array}{c}0.04^{\mathrm{b}}(1.87) \\
0.01-0.20\end{array}$ & 14.3 \\
\hline & $\begin{array}{c}\text { Transfer } \\
\text { into container }\end{array}$ & 43 & $\begin{array}{c}5.3(3.20) \\
0.9-40.1\end{array}$ & 87.5 & $\begin{array}{c}0.05^{\mathrm{c}}(2.25) \\
0.01-0.29\end{array}$ & 16.7 \\
\hline & Total & 77 & $\begin{array}{c}5.9(12.61) \\
0.9-46.3\end{array}$ & 93.3 & $\begin{array}{c}0.05^{\mathrm{d}}(3.40) \\
0.01-0.29\end{array}$ & 15.6 \\
\hline
\end{tabular}

$\mathrm{n}$ - number of samples; $\mathrm{x}_{\mathrm{g}}$ - geometric mean; GSD - geometric standard deviation; $\mathrm{x}_{\min }-\mathrm{x}_{\max }-$ range; letters indicate statistically significant differences $(\mathrm{p}<0,01)$ compared in column; ${ }^{*}$ - dust containing chrysotile; ${ }^{* *}$ - dust containing chrysotile, crocidolite and amosite [20]; ${ }^{* * *}$ - length (L) $>5 \mu \mathrm{m}$; diameter (D) $<3 \mu \mathrm{m}$; aspect ratio (L/D) $>3: 1$

weighted average and $0.15 \mathrm{f} / \mathrm{cm}^{3}$ as median of short-term exposure in New Zealand's construction industry. The exposure study was realized in 9 various projects, when workers were involved in demolition or renovation of asbestos-containing buildings. In the demolition site with high asbestos content material the exposure level was $0.871 \mathrm{f} / \mathrm{cm}^{3}$. Based on the guidance published by WorkSafe New Zealand, dust levels normally found in common industrial situations at controlled wet removal work with "asbestos cement sheeting" is up to $0.5 \mathrm{f} / \mathrm{cm}^{3}$ [11]. However, our average result of personal measurements at removal of asbestos from cooling towers was $0.05 \mathrm{f} / \mathrm{cm}^{3}$. Unlike the average of respirable fibres, concentration during A-C sheets removal work outside various types buildings after Bujak-Piertek and Szadkowska-Stańczyk was $0.014 \mathrm{f} / \mathrm{cm}^{3}$ [12] (the authors did not explain whether or not that was personal measurements at workplaces). Exposure to asbestos of construction workers in France in 1997-2007 was in the range 0.009-2.0 $\mathrm{f} / \mathrm{cm}^{3}$ [6]. On our results of the range of asbestos fiber concentrations in workplaces air during removal of A-C sheets from facades of residential buildings and from fills of cooling towers was narrower $\left(0.03-0.90 \mathrm{f} / \mathrm{cm}^{3}\right.$ and 0.01-0.29 f/ $/ \mathrm{cm}^{3}$, respectively). Higher results were received in the experiment prepared by Canadian researchers. Workers scraped asbestos-containing materials, used a small broom for cleaning surfaces, and moved scaffolds and bags with debris. Asbestos wall tiles were made with $5-10 \%$ of chrysotile. In this project mean concentration was $6.3 \mathrm{f} / \mathrm{cm}^{3}$ and standard deviation was $2.2 \mathrm{f} / \mathrm{cm}^{3}[13]$.

The difference of exposure to asbestos fibres and total dust between removal workers at buildings and at cooling towers is surprising. For buildings, removal workers versus cooling towers removal workers the average of respirable fibre concentrations is 3 -fold higher $\left(0.14 \mathrm{f} / \mathrm{cm}^{3}\right.$ and $0.05 \mathrm{f} / \mathrm{cm}^{3}$, respectively), while for the total dust there is the opposite relationship $\left(1.9 \mathrm{mg} / \mathrm{m}^{3}\right.$ and $5.9 \mathrm{~m} \mathrm{mg} / \mathrm{m}^{3}$, respectively). This mismatch, observed at every kind of work, may be due to differences in the structure and the use of both types of constructions, as well work practices in the period 2000-2005. A-C boards on blocks of flats were not corroded. The workers removed dry and unbroken a-c sheets using hand tools

Table 2. Fibre size distribution in workplace air.

\begin{tabular}{|c|c|c|c|c|c|c|c|c|c|}
\hline \multirow{2}{*}{$\begin{array}{l}\text { Workplace } \\
\text { /fibres size }\end{array}$} & \multirow[t]{2}{*}{$\mathrm{n}$} & \multicolumn{4}{|c|}{$\begin{array}{c}\text { Length } \\
{[\%]}\end{array}$} & \multicolumn{4}{|c|}{$\begin{array}{c}\text { Diameter } \\
{[\%]}\end{array}$} \\
\hline & & $\leq 10.0 \mu \mathrm{m}$ & $10.1-20.0 \mu \mathrm{m}$ & $20.1-50.0 \mu \mathrm{m}$ & $>50.0 \mu \mathrm{m}$ & $\leq 1.0 \mu \mathrm{m}$ & $1.1-2.0 \mu \mathrm{m}$ & $2.1-3.0 \mu \mathrm{m}$ & $>3.0 \mu \mathrm{m}$ \\
\hline Block of flats* & 24 & 51.0 & 23.5 & 17.2 & 8.3 & 50.8 & 22.9 & 16.7 & 9.6 \\
\hline Cooling tower ${ }^{* *}$ & 17 & 55.0 & 25.6 & 19.4 & 0.0 & 68.9 & 20.8 & 9.1 & 0.2 \\
\hline
\end{tabular}

$\mathrm{n}$ - number of samples; ${ }^{*}$ - dust containing chrysotile and mineral wool fibres; ${ }^{* *}$ - dust containing chrysotile, crocidolite and amosite fibres [20]; $\leq$ - less than or equal to; $>$ - above 
(e.g., hammers, crowbars) and drills to unscrew them from the walls. At the same time they removed the heavily damaged mineral wool. The staffs worked on narrow and curtain-shielded scaffolding. They were very close to the dust emission sources. Otherwise, corrugated A-C sheets in fills of cooling towers were badly corroded but soaked with water. They were loosely, vertically placed inside the fill. Workers manually took out the sheets, often broken and crumbled. Dust from corroded steel structures of fill have dropped on removal workers. They contained iron oxides and hydroxides (rust), in which specific gravity is more than 2 times higher than that of asbestos-cement.

In Poland, asbestos exposure level of workers performing demolition is estimated as low [1]. Our observation of asbestos-removing practices from both the residential and the industrial cooling towers confirms that employees frequently worked longer than 8-hour shifts. During intensive removal works working time exceeded 40-hours per week, up to 80 hours per week. The risk of asbestosis increases with increasing cumulative doses (in years), based on the concentrations of respirable asbestos fibers obtained in personal measuring [7]. Breathing the respirable asbestos fibers (of length $>5 \mu \mathrm{m}$, diameter $<3 \mu \mathrm{m}$, and aspect ratio $>3: 1)$ can cause non-cancer diseases of respiratory system (asbestosis, pleural disease) and some certain cancers (pleural and peritoneal mesothelioma, lung cancer - especially if occupational exposure to asbestos is accompanied by tobacco smoking). Mesothelioma occurs mainly as a result of exposure to crocidolite [14], which has been proven in the corrugated A-C sheets installed in the fills of cooling towers. A British questionnaire study on worker mortality for each type of cancer is evidence that that the risk of death increases with the number of hours worked in contact with asbestos [15]. Removal workers employed in 2000-2005 were exposed not only to higher cumulative doses of asbestos fibers, but also other factors associated with such long working hours. Bannai and Tamakoshi [16] and Caruso [17] listed physical fatigue, heat stress, poor diet, and intense smoking. Together they can have a similar negative impact on Polish workers, as it results from the research of Frost et al. [15]. Browsing the list of publications focused on measurements of asbestos fibres, we found an important subject. Egilman et al. [18] perceived the issue concerned corporate manipulation of results of measurements and exposure levels regarding asbestos fibres and the relationship between asbestos and cancer as an occupational disease. Furthermore, Mannetje [10] got the information, based on her questionnaire study of demolition worker safety in workplaces, that required asbestos work practices after administrative controls (when a supervisor be present) were poorly achieved. On the other hand, Choi and Paik [19] could not conduct a part of the survey of asbestos contamination in industrial buildings in Korea "due to the non-cooperative attitude of the employers." These problems also reflect our negative experiences.

\section{Conclusions}

Removal workers at buildings and at cooling towers have been exposed in the past to exceeded concentrations of asbestos dust. Ambient air at residential building workplaces was chrysotile fiber-contaminated. In industrial buildings workplace ambient air contained fibers of crocidolite, chrysotile, and amosite. Exposure to respirable asbestos fibers of workers who stripped off a-c sheets and who transported asbestos debris was similar.

\section{Acknowledgements}

A special thank you to Anna Niesler for assistance in conducting statistical analysis and insightful comments on this paper. The authors also thank Iwona Dobrzelecka and Jolanta Cembrzyńska for the possibility of using a part of the archived results.

\section{Conflict of Interest}

The authors declare no conflict of interest.

\section{References}

1. SZESZENIA-DĄBROWSKA N., ŚWIĄTKOWSKA B. Asbestos in Poland. Environmental pollution, health effects and safe working practices. Institute of Occupational Medicine, Łódź, 2016 [In Polish].

2. NATIONAL INSTITUTE FOR OCCUPATIONAL SAFETY AND HEALTH (NIOSH). Asbestos and other fibers by PCM: Method 7400 ( $4^{\text {th }}$ ed.) Cincinnati: NIOSH, Department of Health and Human Services 2, 1, 1994.

3. Regulation of the Minister of Health of the 2 February 2011 on the tests and measurements of agents harmful to health in the work environment. Journal of Laws, No. 33, item 166, 2011 [In Polish].

4. Regulation of the Ministry of Labor and Social Policy of the 6 June 2014 on the maximum admissible concentrations and intensity of agents harmful to health in the work environment. Journal of Laws, No. 0, item 817, 2014 [In Polish].

5. SĄKOL G., BREWCZYŃSKI P. Z., BIENEK M. The DSH method of X-ray diffraction analysis for identification of asbestos in bulk insulation samples. Medycyna Środowiskowa-Environmental Medicine 15 (3), 72, 2012.

6. KAUFFER E., VINCENT R. Occupational exposure to mineral fibers: analysis of results stored on COLCHIC database. Ann. Occup. Hyg. 52 (2), 131, 2007.

7. OLSSON A. C., VERMEULEN R., SCHÚZ J., KROMHOUT H., PESCH B., PETERS S., BEHRENS T., PORTENGEN L., MIRABELLI D., GUSTAVSON P., KENDZIA B., ALMANSA J., LUZON V., VLAANDEREN J., STÜCKER I., GUIDA F., CONSONNI D., CAPOROSO N., LANDI M. T., FIELD J., BRÜSKE I., WICHMANN H-E., SIEMIATYCKI J., PARENT M-E., RICHIARDI L., MERLETTI F., JÖCKEL K-H., AHRENSW., POHLABELN H., PLATO N., TARDÓN 
A., ZARIDZE D., McLAUGHLIN J., DEMERS P., SZESZENIA-DĄBROWSKA N., LISSOWSKA J., RUDNAI P., FABIANOVA E., DUMITRU R. S., BENCO V., FORETOVA L., JANOUT V., BOFFETTA P., BUENOde-MESQUITA B., FORASTIERE F., BRÜNING T., STRAIF K. Exposure-response analyses of asbestos and lung cancer subtypes in a pooled analysis of case-control studies. Epidemiology 28 (2), 288, 2017.

8. BROWN S.K. Asbestos exposure during renovation and demolition of asbestos-cement clad buildings. J. Occup. Environ. Hyg. 48 (5), 478, 1987.

9. KAKOOEI H., NORMOHAMMADI M. Asbestos exposure among costruction workers during demolition of old houses in Teheran, Iran. Ind. Health 52, 71, 2014.

10. MANNETJE A. Workplace exposure to carcinogens in New Zeland (HCR08/569). Study report to the Departament of Labour, 2013. Available online: http://publichealth. massey.ac.nz/assets/ProjectsPDF/OCCUPATIONALCARCINOGENS-STUDY-08-569-Report.pdf (Accessed 11 September 2017).

11. WORKSAFE NEW ZELAND. Management an removal of asbestos. Approved code of practice, 2016. Available online: http://construction.worksafe.govt.nz/assets/guides/ asbestos-acop/removal-of-asbestos-acop.pdf (Accessed 11 September 2017)

12. BUJAK-PIETREK S., SZADKOWSKA-STAŃCZYK I. Exposure to respirable asbestos fibers at various stages of removal work. Med. Pr. 63 (2), 191, 2012.

13. DUFRESNE A., DION C., FRIELAENDER A., AUDET E., PERRAULT G. Personal and static sample measurements of asbestos fibres during two abatement projects. Bull Environ Contam Toxicol 82, 440, 2009.
14. SZESZENIA-DĄBROWSKA N., ŚWIĄTKOWSKA B., SOBALA W., SZUBERT Z., WILCZYŃSKA U. Asbestos related diseases among workers of asbestos processing plants in relation to type production and asbestos use. Med. Pr. 66, 1, 2015.

15. FROST G., HARDING A-H., DARNTON A., McELVENNY D., MORGAN D. Occupational exposure to asbestos and morality among asbestos removal workers: a Poisson regression analysis. Br. J. Cancer 99, 822, 2008.

16. BANNAI A., TAMAKOSH A. The association between long working hours and health: A systematic review of epidemiological evidence. Scand. J. Work. Environ. Health 40 (1), 5, 2014.

17. CARUSO C.C. Possible broad impacts of long work hours. Ind. Health 44, 531, 2006.

18. EGILMAN D., BIRD T., LEE C. Dust diseases and the legacy of corporate manipulation of science and law. Int $\mathrm{J}$ Occup Med Environ Health 20 (2), 115, 2014.

19. CHOI S., PAIK N. W. Asbestos-containing material and airborne asbestos levels in industrial buildings in Korea. J UOEH 32 (1), 31, 2010.

20. SĄKOL G., MUSZYŃSKA-GRACA M. Removal of asbestos-cement sheets and occupational and environmental exposure to asbestos. Medycyna Środowiskowa-Environmental Medicine 20 (3), 21, 2017 [In Polish]. 
